\title{
Out-of-pocket expenditure and distress financing on institutional delivery in India
}

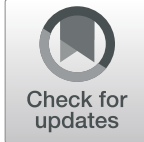

Suyash Mishra ${ }^{1 *}$ (D) and Sanjay K. Mohanty ${ }^{2}$

\begin{abstract}
Background: Despite large investment in central and state sponsored schemes for maternal care, out-of-pocket expenditure (OOPE) and catastrophic health spending $(\mathrm{CHS})$ on institutional delivery remain high over time, across states and across socio-economic groups. Though many studies have examined the OOPE and CHS, few studies have examined the nature and extent of distress financing on institutional delivery in India.

Data: Data from the fourth round of National Family Health Survey (NFHS 4), 2015-16 was used for the analysis. Distress financing was defined as borrowing money or selling assets to meet the OOPE on delivery care. Composite variables, descriptive analyses, concentration index $(\mathrm{Cl})$, concentration curve $(\mathrm{CC})$ and predicted probability were used to estimate the extent of distress financing for institutional delivery in India.

Results: The OOPE on institutional delivery has strong economic and educational gradient. One in four mothers resorted to borrowing or selling to meet the OOPE on institutional delivery. The extent of distress financing on institutional delivery was high in poorer state of Bihar and Odisha and in the state of Telangana that had highest prevalence of caesarean delivery. Savings was more prevalent among mothers compared to those who met the OOPE by borrowing/selling of assets. Finding are robust across the states of India. The predicted probability of incurring distress financing was 0.31 among mothers belonging to the poorest wealth quintile compared to 0.09 in the richest quintile, and 0.40 for those who incurred OOPE of more than INR 20,000. The probability of incurring distress financing was higher for mothers who had caesarean birth, delivered in private health centers and incurred high OOPE on institutional delivery.
\end{abstract}

Conclusion: Distress financing on institutional delivery was higher among the less educated, poor and in private health centers. Increasing use of public health centers, reducing caesarean births, improving the availability of medicine and diagnostic services can reduce the extent of distress financing in India.

Keywords: Institutional delivery, India, OOPE, Coping strategy, Distress financing

\section{Introduction}

High and increasing health care cost is one of the major public health challenges in developing countries. While the household remains the major source of financing health care, the extent of poverty, impoverishment and indebtedness due to high out-of-pocket expenditure (OOPE) is on the rise [1-4]. An estimated 808 million people across 133 countries are said to have incurred catastrophic health spending (CHS) [5]. CHS varies enormously across and within countries and is consistently high among the poor, less educated, uninsured,

\footnotetext{
* Correspondence: suyashmishra1592@gmail.com

1 International Institute for Population Sciences, Govandi Station Road,

Deonar, Mumbai 400088, India

Full list of author information is available at the end of the article
}

rural households, female headed households, households with members suffering from chronic illness and households with older people [6, 7]. Reduction of CHS has been integrated into global development agenda (SDGs) [8]. Besides CHS, high OOPE on medical care makes poor households poorer and drives non-poor household into poverty. About 97 million people in 2010 became impoverished ( $\$ 1.90$ per day poverty line) due to out of pocket health spending across 122 countries [9]. Households resort to multiple means to cope with the increasing OOPE on health care including current income, savings, selling of assets, borrowing from moneylenders and reduction in consumption expenditure. The adverse

(c) The Author(s). 2019 Open Access This article is distributed under the terms of the Creative Commons Attribution 4.0 International License (http://creativecommons.org/licenses/by/4.0/), which permits unrestricted use, distribution, and 
consequences of borrowing and selling assets to meet OOPE is profound in the short run as well as long run [10-13].

A number of studies coined borrowing and selling of assets by households as distress financing of health care [14-19]. Distress financing varies largely by the nature of the disease, type of facility used and the economic wellbeing of the household. The poor and marginalized are more likely to resort to distress financing across countries [17, 20,21]. The causes of distress financing are many: high OOPE on healthcare including payments for medicines, consultation and procedure fees, low insurance coverage, financial constraints, and low government spending. Though recent literature has focused more on OOPE and CHS on health care, there is little emphasis on the source of meeting OOPE on health care. About 150 million people suffered from distress financing in seeking healthcare services [22]. OOPE on health care has an adverse impact on the economic wellbeing of individuals forcing them to resort to distress financing [3, 23-25]. The definition of distress financing is not uniform but is more context-specific $[15,17,20$, 26-29]. The extent, nature and correlates of distress financing for meeting health expenditure varies across countries $[15,16,19,27,30,31]$. A number of studies from low and middle-income countries suggests that borrowing from relatives and friends, loans from money lenders and financial institutions, mortgaging assets, selling assets, selling livestock and selling harvest crops are common forms of distress financing [3, 25, 32-34]. Studies observe that other coping strategies to meet health care cost were reducing household food and nonfood expenditure and increasing working hours for extra income [35]. Income diversification, selling of assets and borrowing money was common practice to meet the direct health care costs while task reallocation among household members was used for meeting the indirect costs of illness in low-income countries [36]. Poor households, households residing in rural areas, households suffering from multiple ailments and chronic diseases are more likely to incur distress financing $[3,17$, 20, 29, 30, 37-40]. The borrowing and selling of assets was higher for treating tuberculosis and antiretroviral services as compared to obstetric care in South Africa [31]. Studies from East European countries suggest that lower health status, lower income, and chronic illness increases the likelihood of distress financing [19]. A study by Adam \& Ke (2008) found that about $30 \%$ of the households across 15 African countries met their health expenditure by borrowing or selling assets [41]. About 26\% of the households in urban India met their health expenditure by borrowing from different sources and 5\% depended on selling of assets and livestock [42].
A number of studies examined the extent, nature and correlates of distress financing on maternal care. In rural Bangladesh, about $40 \%$ of the households relied on loans, donations from friends or relatives, sale of assets or combination of all the sources to meet severe maternal morbidity and about half of the households were able to avoid catastrophic health spending because of the coping strategies [27]. A study from three African countries revealed that about one-third of the women relied on selling of assets and crops to pay for delivery care expenses [43]. About $17.4 \%$ of the women from the lowest quintile in Mumbai slums financed the maternal care expenditure by borrowing [44]. Modugu et al. 2012 found that distress financing was higher for caesarean-section deliveries and was associated with high OOPE [45].

The healthcare system in India is characterized by coexistence of public and private health centers, poor public health infrastructure, high health care costs and low insurance coverage. The poor quality of services at public health centers and low insurance coverage lead to increasing use of private health centers and high OOPE in India. OOPE as share of total health expenditure has remained high over time- $69.4 \%$ in 2004, $64.2 \%$ in 2014 and $62.6 \%$ in 2015 [46-48]. During the last one and half decades, the Government of India and the state government have launched a number of financial protection schemes to reduce OOPE and CHS on maternal care. The Janani Suraksha Yojana (JSY) and Janani Shishu Suraksha Karyakram (JSSK) are two such centrally funded schemes under the National Health Mission (NHM) that provide conditional cash incentives to the mothers. The JSY was initiated in 2005 under which mothers delivering at public health centers in Low Performing States (LPS) were entitled to INR 1400 in rural areas and INR 1000 in urban areas and INR 700 in rural areas and INR 600 in urban areas in High Performing States (HPS) (https://www.nhp.gov.in/janani-surakshayojana-jsy-_pg). Introduced in 2011, the JSSK provides free and cashless services to pregnant women for both normal and caesarean deliveries and new-borns up to 30 days in Government health institutions. The Rashtriya Swasthya Bima Yojana (RSBY) was launched by the Government of India in 2008 with the objective of protecting poor households from the financial hardship associated with hospitalization (http://www.rsby.gov.in/how_works. html). In 2018, the Government of India launched the Ayushman Bharat, a centrally sponsored National Health Protection Scheme that aims to provide an annual health cover of up to INR 5 lakh to nearly 10 crore vulnerable poor households. It covered secondary and tertiary treatment, from any public/private empanelled hospitals across the country (https://www.india.gov.in/spotlight/ ayushman-bharat-national-health-protection-mission). 
Besides, there are various state specific Community Health Insurance (CHI). For example, ACCORD, providing health insurance cover to indigenous people in Tamil Nadu and MAMTA provides cash assistance for maternal care and child nutrition in Odisha. While studies on JSY suggest increase in institutional delivery and reduction in OOPE, RSBY did not yield the desired effect [49-51].

The state variations in epidemiological transition (ET) and level of development are large and associated with OOPE, CHS, per capita public health spending and distress financing. Among the 36 states and union territories in India, 9 are classified in low ET, 8 in medium ET and 19 in high ET [52]. The composite Index of Human Development varies from 0.625 in Kerala to 0.442 in Odisha in 2011 [53]. Among the major states of India, the CHS was highest in Kerala (37.2\%) and lowest in Assam (8.9\%) [54]. Small scale studies suggest that the extent of distress financing was high in poorer states $[8,11]$.

Distress financing and CHS are alternative ways to capture the vulnerability of high OOPE. While the CHS is being quantified by alternative methods and debated, the utility of distress financing is its simplicity to capture the high health care costs. Many studies have estimated the extent of distress financing in health care in India $[20,29,33,44,55,56]$, but few have quantified it for delivery care [27, 45]. However, no study has estimated the association of OOPE and coping strategy with delivery care in India. In this context, our study aims to estimate the extent of distress financing on delivery care and its correlates using recently held large scale population based data in India.

\section{Data and method}

We have used the unit data from the fourth round of National Family Health Survey (NFHS 4) conducted during 2015-16. The NFHS 4 has the distinction of being the largest ever population-based survey (sample size, geographical coverage and content) on maternal and child health in India. In line with the Demographic Health Survey, it collected detailed information on demographic, socioeconomic condition of the households, contraception, utilisation of health services and nutritional status of children and mothers. The NFHS 4 has successfully interviewed a total of 601,509 households and 699,686 ever married women in 15-49 age group. A total of 259,627 births were reported in the 5 year preceding the survey, of which 190,898 were of last births and 148,746 were conducted at a health center. The instrument used, results of the survey along with methodology and sampling design is available in the national report [57].
For the first time, NFHS 4 collected information on OOPE on delivery care (defined as the expenditure net of reimbursement) for last birth that was delivered at a health center. Along with data on OOPE, the survey also provides information on source of financing for OOPE on delivery care. The unit data was cleaned for reported errors on OOPE before the analysis. The details and procedure of data cleaning is available elsewhere [58].

\section{Outcome variable}

Distress financing is the outcome variable used in the analyses. A mother was said to be incurring distressed financing if she reported borrowing money or selling assets or reported utilising savings along with borrowing money or selling assets for meeting OOPE on institutional delivery.

\section{Independent variable}

A number of independent variables were used in the analyses. These include: type of delivery, (normal / caesarean), source of delivery care (public/private), ${ }^{1}$ OOPE on delivery care, JSY beneficiary, and individual/household characteristics. The OOPE on institutional delivery was grouped into six categories; less than 1000, $1000-5000$, 5000-10,000, 10,000-15,000, 15,000-20, 000 and higher than 20,000 . The individual characteristics include mothers' age $(15-24,25-34,35+)$, education (no education, primary, secondary, higher), parity (1, 2, 3, 4+), religion (Hindu, Muslim, Others), social group (Scheduled Castes [SCs] Scheduled Tribe [STs], Other Backward Classes [OBCs] and Others). Wealth quintile (poorest, poorer, middle, richer, richest) ${ }^{2}$ is used to reflect the economic status of the households .

\section{Statistical analysis}

Descriptive statistics, composite variables, concentration index (CI), concentration curve (CC) and logistic regression were used in the analyses. To understand distress financing, a composite variable based on various source of financing was computed and categorized into five distinct groups; mothers those (i) used only their savings (ii) either borrowed money or sold assets (iii) used savings and either borrowed money or sold assets (iv) relied on insurance or other sources of financing and (v) did not pay.

The CC and CI were used to discern the economic inequality (measured by wealth index) in distress financing. The CC and CI are commonly used measure in health inequality research [59]. The CC graphically represents the economic inequality and plots the cumulative proportions of the population (ranked by wealth) against the cumulative proportions of population incurring distress financing. Thus, if the extent 
distress financing was evenly distributed across the wealth group, then the $\mathrm{CC}$ would coincide with the line of equality. However if CC lies above the line of equality, suggesting the concentration of distress financing among mother belonging to poor households while if CC lies below the line of equality, it implies concentration of distress financing among mothers belonging to rich households. The CI is derived from CC and is defined as twice the area between the concentration curve and line of equality, ranging from -1 to +1 . The closer the $\mathrm{CI}$ value to 1 (absolute), the more unequal is distress financing across the wealth group while a zero value of CI suggest equal distribution of distress financing across the wealth group. The logistic regression (state fixed effect model) was used to predict the probability of distress financing on delivery care. The outcome variable has been coded as 1 if the mother incurred distress financing and 0 otherwise. The general form of the regression model is given as:

$$
\begin{aligned}
\operatorname{logit}\left(\pi_{\mathrm{i}}\right)=\alpha & +\beta_{1}\left(\text { place of residence }_{\mathrm{i}}\right) \\
& +\beta_{2}\left(\text { age }_{\mathrm{i}}\right)+\beta_{3}\left(\text { education }_{\mathrm{i}}\right) \\
& +\beta_{4}\left(\text { (religion }_{\mathrm{i}}\right)+\beta_{5}\left({\text { social } \left.\text { group }_{\mathrm{i}}\right)}\right) \\
& +\beta_{6}\left(\text { birth order }_{\mathrm{i}}\right)+\beta_{7}\left(\text { wealth quintile }_{\mathrm{i}}\right) \\
& +\beta_{8}\left(\text { (ource of delivery }_{\mathrm{i}}\right) \\
& +\beta_{9}\left(\text { type of delivery }_{\mathrm{i}}\right) \\
& +\beta_{10}\left(\text { JSY beneficiary }_{\mathrm{i}}\right)+\beta_{11}\left(\text { OOPE }_{\mathrm{i}}\right)+\mathrm{e}_{\mathrm{i}}
\end{aligned}
$$

where $\pi_{i}$ is the probability of incurring distress financing by the $\mathrm{i}^{\text {th }}$ women on institutional delivery, $\alpha$ is the intercept and $\beta$ 's are the slope parameter. Results of the regression analyses are presented with the help of predicted probabilities. The analysis was restricted only to those states which had a minimum sample of 200 mothers.

\section{Results}

\section{OOPE by wealth tertile and educational attainment}

Table 1 presents the mean OOPE by wealth tertile and educational attainment of mothers in the states of India. In general, OOPE increases with wealth tertile suggesting that OOPE is associated with the households' ability to pay. The mean OOPE among mothers belonging to the poorest wealth tertile was 2.5 times higher than that of the richer tertile. The pattern is similar with respect to educational attainment. Besides, OOPE on institutional birth varies enormously across the states of India. It was lowest in Madhya Pradesh (INR 4150) followed by Bihar (INR 4765) and highest in Kerala (INR 16149) followed by Delhi (INR 14960) and Manipur (INR 14822). In general, the OOPE was higher in economically better off states and low in the poorer states of India. The OOPE was higher in Telangana, which has recorded the highest caesarean deliveries in India. Similarly, the mean OOPE of an institutional birth of mothers with no education was INR 4382 compared to INR 9703 those with more than 7 years of schooling. The ratio of OOPE among mothers with 7 years of schooling and more to illiterate mothers was highest in Assam (3.53) and least in Delhi (0.49). The OOPE increases with wealth tertile and educational attainment, thereby suggesting that the richer and educated parents might be seeking better quality of care and care from private health centers.

\section{Source of financing for institutional delivery}

Figure 1 shows the distribution of source of financing for institutional delivery across selected states of India. The state variation in source of financing for delivery care is large. Among the states, about $28 \%$ of the mothers in Himachal Pradesh and 27\% of the mothers from Haryana did not pay for institutional delivery while it was lowest in West Bengal (3.2\%) and Bihar (3.9\%). It was 25\% in Madhya Pradesh, 24\% in Chhattisgarh and less than 7\% in Uttar Pradesh. Over 60\% of the mothers in the states of Punjab, Maharashtra, Gujarat, Meghalaya, Delhi, Rajasthan, Uttarakhand, Himanchal Pradesh, Kerala, Jammu and Kashmir, West Bengal, Uttar Pradesh, Chhattisgarh and Jharkhand paid from their savings. The proportion of mothers who met their expenses on institutional delivery by borrowing or selling assets was highest in the states of Telangana (29\%) and Bihar (28.8\%) followed by Tamil Nadu (26\%) and Odisha (23.4\%). About half of the women in Telangana had caesarean delivery and the cost of a caesarean delivery was at least three times higher than that of vaginal delivery [58]. Those who met the expenses on institutional delivery through combined means of saving, selling and borrowing was highest in Manipur (17.4\%) followed by Uttar Pradesh (10.2\%). From the analyses it is clear that the extent of distress financing on institutional delivery varies largely across the states of India.

Table 2 presents the mean OOPE on institutional delivery by source of financing across the states of India. The mean OOPE for mothers resorting to only saving for institutional delivery was highest in Kerala (INR. 19, 076) followed by Delhi (INR 18994) and Manipur (INR 14480), while it was lowest in Bihar (INR 4271) followed by Madhya Pradesh (INR 5227). The mean OOPE for mothers relying on only selling and borrowing was highest in Kerala (INR 20621) followed by Telangana (INR 17618) and Manipur (INR 15625) while it was lowest in Assam (INR 4138) followed by Meghalaya (INR 5034). It was highest in Kerala for those who met the expenses on institutional delivery through savings along with selling and borrowing (INR 25994) followed by Delhi (INR 
Table 1 Mean OOPE on Institutional Delivery by Wealth Tertile and Educational Attainment in the States of India, 2015-16

\begin{tabular}{|c|c|c|c|c|c|c|c|c|}
\hline \multirow[t]{3}{*}{ State } & \multirow{3}{*}{$\begin{array}{l}\text { Mean OOPE } \\
\text { (INR) }\end{array}$} & \multicolumn{3}{|c|}{ Mean OOPE (INR) } & \multicolumn{3}{|c|}{ Mean OOPE (INR) } & \multirow[t]{3}{*}{$\mathrm{N}$} \\
\hline & & \multicolumn{3}{|c|}{ Wealth Tertile } & \multicolumn{3}{|c|}{ Education } & \\
\hline & & Poor & Middle & Rich & Illiterate & $1-6$ years & $7+$ years & \\
\hline Andhra Pradesh & 7946 & 5258 & 7395 & 9513 & 5927 & 6585 & 8920 & 5964 \\
\hline Assam & 6121 & 3590 & 5789 & 14,361 & 2196 & 3557 & 7747 & 3713 \\
\hline Bihar & 4765 & 3834 & 5843 & 9156 & 3393 & 4454 & 6639 & 13,667 \\
\hline Chhattisgarh & 5278 & 2474 & 4182 & 10,280 & 1991 & 3363 & 6882 & 3216 \\
\hline Gujarat & 8742 & 4801 & 6617 & 11,337 & 5335 & 7624 & 10,009 & 7306 \\
\hline Haryana & 6643 & 4682 & 3243 & 7557 & 3896 & 4911 & 7583 & 3439 \\
\hline Himachal Pradesh & 6027 & 4321 & 3741 & 6715 & 3650 & 3736 & 6217 & 685 \\
\hline Jammu and Kashmir & 5371 & 3817 & 4285 & 6684 & 3946 & 4013 & 6164 & 1467 \\
\hline Jharkhand & 5869 & 3712 & 7506 & 11,031 & 3011 & 5213 & 7387 & 3478 \\
\hline Karnataka & 10,197 & 5412 & 7486 & 14,158 & 4553 & 6806 & 11,807 & 7412 \\
\hline Kerala & 16,149 & 4887 & 10,217 & 17,177 & 5837 & 10,067 & 16,261 & 3659 \\
\hline Madhya Pradesh & 4150 & 2127 & 3207 & 7644 & 2064 & 2626 & 5778 & 9898 \\
\hline Maharashtra & 9838 & 6230 & 8203 & 12,110 & 6425 & 6918 & 10,620 & 14,355 \\
\hline Manipur & 14,822 & 11,563 & 13,751 & 18,041 & 12,587 & 12,978 & 15,202 & 282 \\
\hline Meghalaya & 6770 & 4515 & 6300 & 11,405 & 3885 & 4432 & 8447 & 291 \\
\hline Delhi & 14,960 & 19,934 & 10,139 & 15,686 & 27,937 & 6890 & 13,722 & 2035 \\
\hline Odisha & 5337 & 3964 & 5548 & 9412 & 2814 & 4092 & 6593 & 5750 \\
\hline Punjab & 8488 & 3013 & 4433 & 9229 & 4027 & 5226 & 9696 & 2976 \\
\hline Rajasthan & 5573 & 3948 & 5435 & 7240 & 4213 & 5195 & 6847 & 8860 \\
\hline Tamil Nadu & 10,063 & 4440 & 6628 & 13,615 & 4334 & 5945 & 10,931 & 10,792 \\
\hline Tripura & 6344 & 4589 & 7383 & 9353 & 3257 & 4500 & 7188 & 424 \\
\hline Uttar Pradesh & 6747 & 3932 & 6796 & 11,056 & 4342 & 5145 & 8795 & 21,436 \\
\hline Uttarakhand & 7735 & 4251 & 4700 & 9862 & 5666 & 5847 & 8479 & 1059 \\
\hline West Bengal & 11,005 & 8985 & 12,360 & 13,495 & 5995 & 10,304 & 12,220 & 10,890 \\
\hline Telangana & 13,567 & 11,059 & 11,962 & 15,247 & 11,011 & 11,776 & 14,496 & 4771 \\
\hline India & 7978 & 4578 & 7154 & 11,527 & 4382 & 5976 & 9703 & 148,746 \\
\hline
\end{tabular}

22340) and Karnataka (INR 21374). In the poorer states of Bihar and Uttar Pradesh, the mean OOPE among mothers who met the expenses on institutional delivery by selling or borrowing only was INR 5585 and INR 6788 rupees respectively. Results show that the OOPE was similar for those who met delivery expenses with savings or with borrowing/selling, but at least twice higher among those who met it through savings along with borrowing and selling. This further confirms that high OOPE on institutional delivery is leading to borrowing and selling assets.

Table 3 shows the extent of distress financing by selected socio-demographic characteristics in India, Bihar and Telangana. The extent of distress financing was highest in Telangana followed by Bihar and so these two states are used for illustration. The extent of distress financing was higher in rural areas compared to urban areas, higher among mothers with low educational attainment and belonging to the poorest and poorer wealth quintiles. About $31.8 \%$ of the mothers with no education in India met OOPE on institutional delivery through distress financing compared to 17.3\% among those with higher secondary education and above. Similarly, about $41.8 \%$ of the others belonging to the poorest wealth quintile in Bihar incurred distress financing compared to $10.7 \%$ among the richest wealth quintile in the state. The extent of distress financing was higher among mothers belonging to socially disadvantaged groups (SC/ST) compared to mothers belonging to others group. Mothers using private health centers for institutional delivery reported high distress financing compared to mothers using public health centers (27.8\% vs. $23.4 \%)$. Mothers experiencing caesarean delivery reported higher distress financing compared to mothers having normal delivery (30.9\% vs. $23.1 \%)$. The extent of distress financing also increases with OOPE. About $12.5 \%$ of the mothers who had an OOPE of less than INR 1000 financed incurred distress financing 


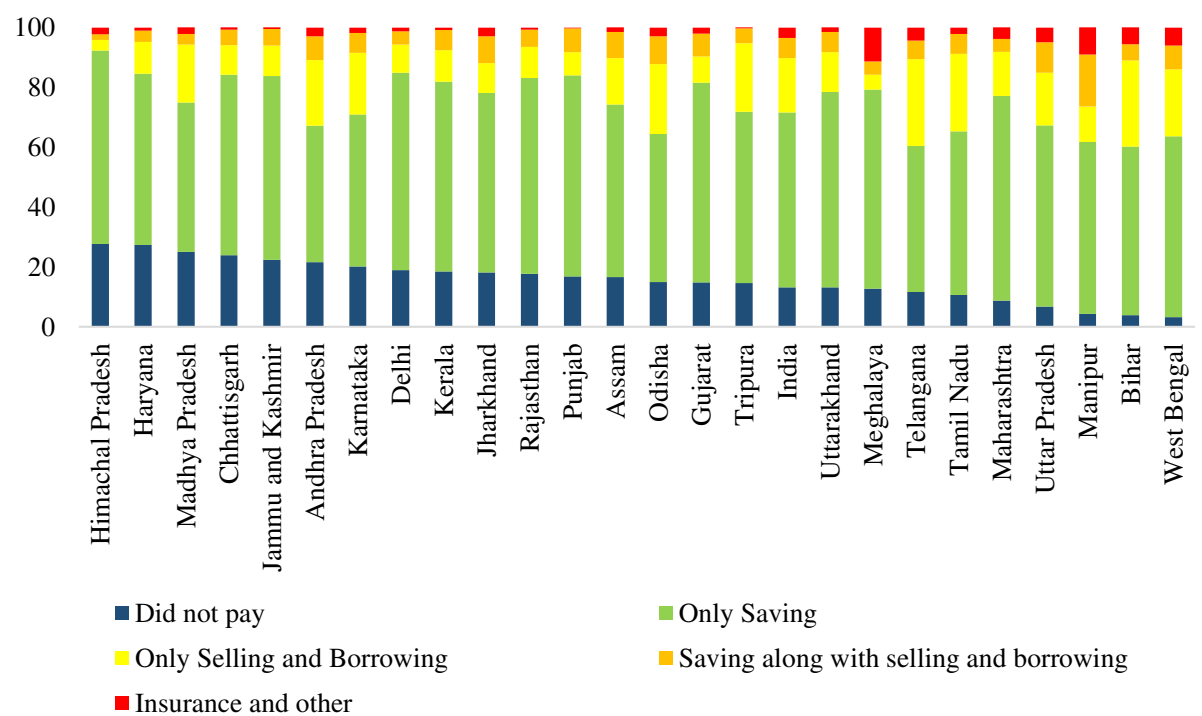

Fig. 1 Source of Financing for Institutional Delivery in the States of India, 2015-16

compared to $34.9 \%$ of the mothers who spent INR 20000 and more.

Table 4 presents the concentration index for institutional delivery by source of financing in selected states of India. We present the CI for those mothers who met OOPE on institutional delivery with only saving, only by selling and borrowing, savings along with selling and borrowing and distress financing (any form of selling or borrowing). The $\mathrm{CI}$ value for mothers using only savings to meet OOPE on institutional delivery was 0.084 for India, and positive for all the states of India suggesting that savings was largely used to meet the OOPE among mothers belonging to rich households. At state level, the CI value of saving was highest in Madhya Pradesh (0.131) followed by Manipur (0.124) and least in Andhra Pradesh (0.028). Further the CI values for mothers using only selling and borrowing for institutional delivery was -0.235 for India and was negative for all the states indicating that selling and borrowing only was largely used among mothers belonging to poor households. Similarly CI value for mothers incurring distress financing was -0.171 for India and was negative for all the states. For instance, the $\mathrm{CI}$ value for mothers using only selling and borrowing was highest in Himachal Pradesh (-0.442) followed by Meghalaya (- 0.416) and least for Andhra Pradesh $(-0.081)$ whereas the $\mathrm{CI}$ value for mother incurring distress financing for institutional delivery was highest in Kerala $(-0.316)$ followed by Jammu \& Kashmir $(-0.312)$ and least in Karnataka (-0.052). Figure 2 presents the CC for mother meeting OOPE through savings only, Fig. 3 presents the CC for mothers meeting the OOPE through selling and borrowing only and Fig. 4 presents the $\mathrm{CC}$ for mothers incurring distress financing for institutional delivery. The $\mathrm{CC}$ for mother using only savings to meet OOPE for institutional delivery was below the line of equality suggesting higher concentration of use of savings among mothers belonging to rich households. The $\mathrm{CC}$ for mothers using only selling and borrowing and incurring distress financing was above the line equality suggesting that the use of selling and borrowing and incurring distress financing among mothers belonging to poor households.

Table 5 presents the predicted probability of incurring distress financing on institutional delivery adjusting for socio-economic and demographic characteristics of mothers and households in India, Bihar and Telangana. Results suggests that place of residence, mother's education, social group, wealth quintile, type of delivery and out-ofpocket expenditure are significant predictors of distress financing in India. The predicted probability of incurring distress financing among mothers residing in rural and urban India (0.19) was similar. For illiterate mothers, the predicted probability of incurring distress financing was 0.23 compared to 0.14 for mothers with higher education level. The predictive probability of incurring distress financing has a strong economic gradient- 0.31 for mothers belonging to the poorest wealth quintile, 0.26 for poorer, 0.20 for middle, 0.15 for richer and 0.09 for the richest wealth quintile. The predicted probability of incurring distress financing for mothers having caesarean birth was 0.21 compared to 0.18 for normal delivery. For mothers who incurred OOPE of more than INR 20000 on institutional delivery (.41), the predicted probability of incurring distress financing was approximately five times higher than mothers who incurred OOPE of less than INR 1000 (0.09). The state pattern was similar in many of these covariates.

\section{Discussion}

Increasing institutional delivery and reduction of high OOPE and CHS on maternal care had received program 


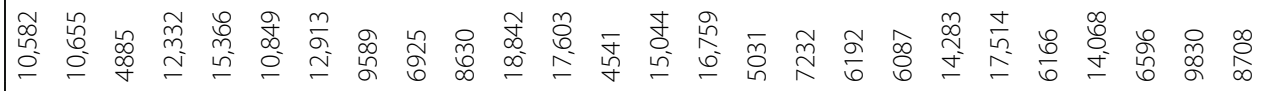

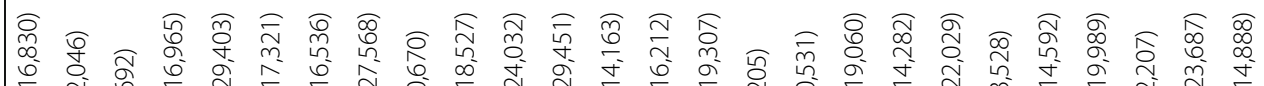

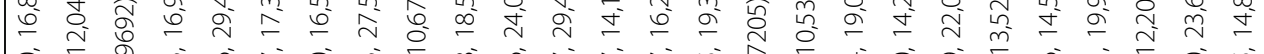

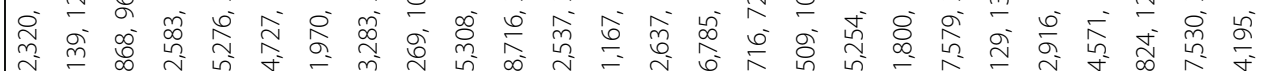

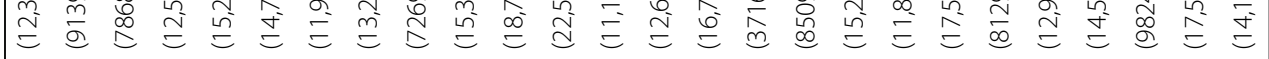

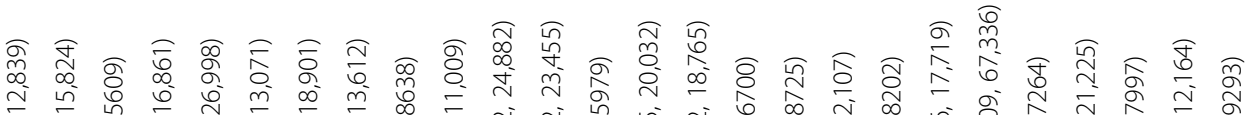

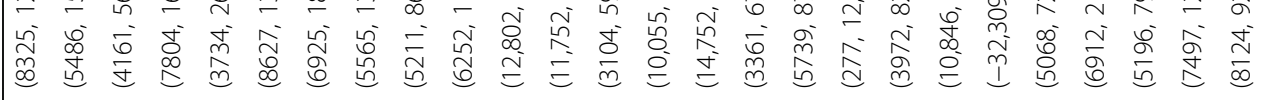

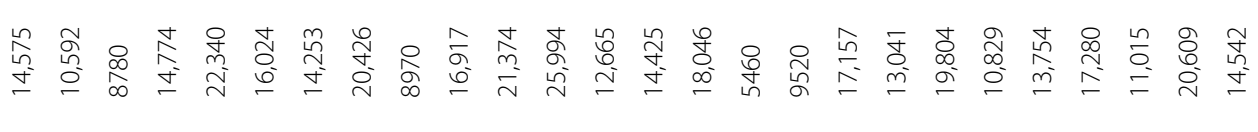

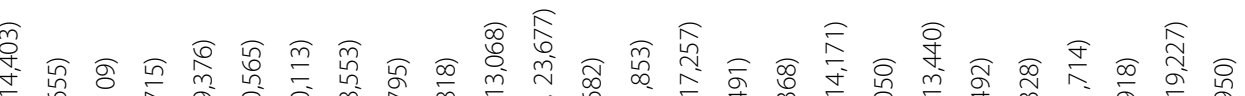

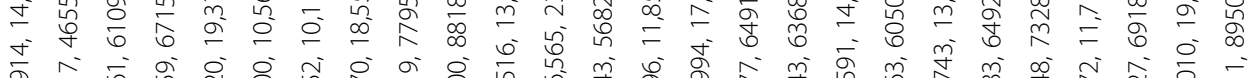

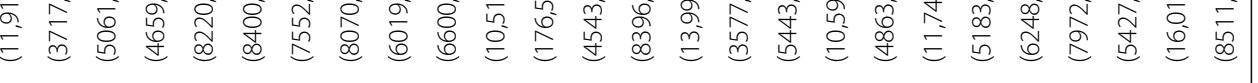

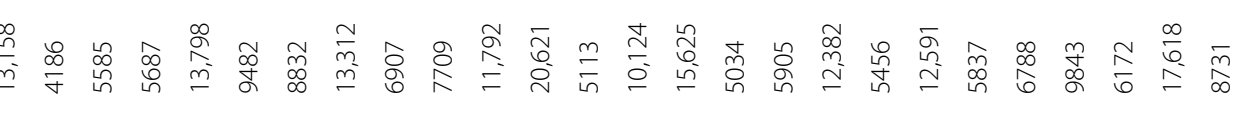

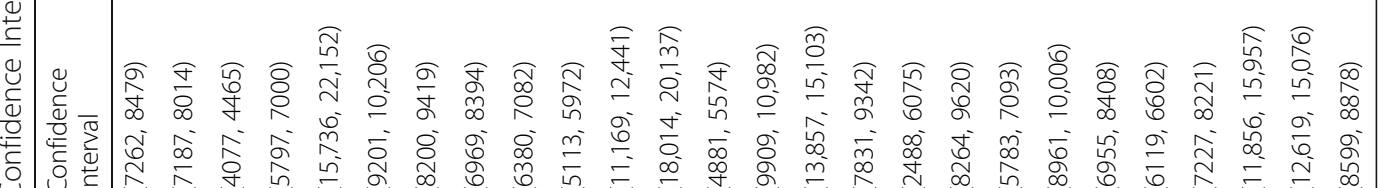

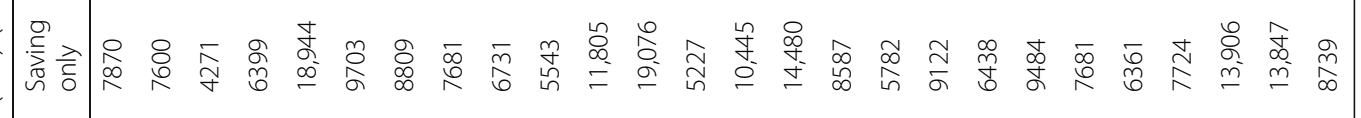

离离 
Table 3 Distress Financing by Selected Socio-demographic Characteristics in India, Bihar and Telangana, 2015-16

\begin{tabular}{|c|c|c|c|c|c|c|}
\hline \multirow[b]{2}{*}{ Variables } & \multicolumn{2}{|l|}{ India } & \multicolumn{2}{|l|}{ Bihar } & \multicolumn{2}{|l|}{ Telangana } \\
\hline & $\begin{array}{l}\text { Distress Financing } \\
(\%)\end{array}$ & $\begin{array}{l}\text { Did not pay } \\
(\%)\end{array}$ & $\begin{array}{l}\text { Distress Financing } \\
(\%)\end{array}$ & $\begin{array}{l}\text { Did not pay } \\
(\%)\end{array}$ & $\begin{array}{l}\text { Distress Financing } \\
(\%)\end{array}$ & $\begin{array}{l}\text { Did not pay } \\
(\%)\end{array}$ \\
\hline \multicolumn{7}{|l|}{ Place of Residence } \\
\hline Urban & 20.8 & 12.3 & 22.1 & 3.1 & 27.6 & 12.6 \\
\hline Rural & 27.0 & 13.6 & 35.9 & 4.0 & 42.5 & 10.7 \\
\hline \multicolumn{7}{|l|}{ Age } \\
\hline $15-24$ & 26.0 & 13.6 & 33.3 & 4.0 & 36.7 & 11.1 \\
\hline $25-35$ & 24.2 & 12.9 & 34.4 & 3.7 & 34.3 & 11.8 \\
\hline $35+$ & 28.8 & 12.9 & 42.4 & 5.7 & 16.4 & 30.5 \\
\hline \multicolumn{7}{|l|}{ Education Level } \\
\hline Illiterate & 31.8 & 14.1 & 39.8 & 4.0 & 44.8 & 10.0 \\
\hline Primary & 29.0 & 13.8 & 35.6 & 3.6 & 46.7 & 11.4 \\
\hline Secondary & 25.0 & 13.4 & 30.8 & 3.1 & 35.9 & 12.1 \\
\hline Higher & 17.3 & 11.7 & 19.9 & 4.8 & 26.5 & 12.0 \\
\hline \multicolumn{7}{|l|}{ Religion } \\
\hline Hindu & 24.9 & 13.3 & 33.5 & 3.9 & 36.3 & 11.3 \\
\hline Muslim & 26.5 & 11.8 & 38.3 & 3.7 & 25.4 & 14.1 \\
\hline Other & 21.1 & 14.4 & 65.9 & 0.0 & 37.2 & 11.3 \\
\hline \multicolumn{7}{|l|}{ Social Group } \\
\hline Schedule caste & 27.9 & 13.1 & 34.3 & 4.9 & 34.4 & 13.9 \\
\hline Schedule tribe & 24.5 & 20.0 & 42.1 & 4.7 & 49.0 & 6.7 \\
\hline $\mathrm{OBC}$ & 25.9 & 12.7 & 34.9 & 3.3 & 36.5 & 10.8 \\
\hline General & 21.1 & 11.6 & 29.8 & 4.5 & 24.8 & 14.3 \\
\hline \multicolumn{7}{|l|}{ Birth Order } \\
\hline 1 & 23.9 & 12.9 & 33.6 & 4.1 & 33.3 & 14.6 \\
\hline 2 & 24.2 & 13.1 & 32.0 & 3.5 & 35.4 & 9.7 \\
\hline 3 & 26.0 & 13.9 & 35.6 & 3.5 & 40.4 & 11.1 \\
\hline $4+$ & 29.0 & 13.1 & 36.1 & 4.3 & 29.8 & 12.5 \\
\hline \multicolumn{7}{|l|}{ Wealth Quintile } \\
\hline Poorest & 35.1 & 12.7 & 41.8 & 4.0 & 47.3 & 9.2 \\
\hline Poorer & 29.6 & 13.3 & 32.2 & 3.6 & 40.3 & 10.8 \\
\hline Middle & 26.2 & 13.7 & 25.2 & 4.3 & 43.2 & 10.1 \\
\hline Richer & 21.8 & 13.1 & 20.2 & 3.0 & 34.3 & 12.0 \\
\hline Richest & 13.1 & 12.8 & 10.7 & 3.3 & 21.4 & 13.9 \\
\hline \multicolumn{7}{|l|}{ Source of Delivery } \\
\hline Public health facility & 23.4 & 16.5 & 34.3 & 3.6 & 27.2 & 13.9 \\
\hline Private health facility & 27.8 & 7.0 & 33.8 & 4.5 & 39.0 & 10.5 \\
\hline \multicolumn{7}{|l|}{ Type of Delivery } \\
\hline Normal delivery & 23.1 & 14.5 & 33.8 & 3.9 & 26.7 & 12.1 \\
\hline Caesarean delivery & 30.9 & 8.8 & 37.5 & 3.4 & 39.8 & 11.4 \\
\hline \multicolumn{7}{|l|}{ JSY Beneficiary } \\
\hline No & 25.5 & 11.2 & 35.9 & 3.5 & 36.9 & 10.4 \\
\hline Yes & 24.2 & 15.6 & 33.0 & 3.3 & 23.6 & 16.6 \\
\hline
\end{tabular}

Mean OOPE 
Table 3 Distress Financing by Selected Socio-demographic Characteristics in India, Bihar and Telangana, 2015-16 (Continued)

\begin{tabular}{|c|c|c|c|c|c|c|}
\hline \multirow[b]{2}{*}{ Variables } & \multicolumn{2}{|l|}{ India } & \multicolumn{2}{|l|}{ Bihar } & \multicolumn{2}{|l|}{ Telangana } \\
\hline & $\begin{array}{l}\text { Distress Financing } \\
(\%)\end{array}$ & $\begin{array}{l}\text { Did not pay } \\
(\%)\end{array}$ & $\begin{array}{l}\text { Distress Financing } \\
\text { (\%) }\end{array}$ & $\begin{array}{l}\text { Did not pay } \\
(\%)\end{array}$ & $\begin{array}{l}\text { Distress Financing } \\
\text { (\%) }\end{array}$ & $\begin{array}{l}\text { Did not pay } \\
\text { (\%) }\end{array}$ \\
\hline Less than 1000 & 12.5 & na & 25.7 & na & 11.5 & na \\
\hline $1000-5000$ & 28.4 & na & 36.4 & na & 26.5 & na \\
\hline $5000-10,000$ & 30.6 & na & 37.3 & na & 39.8 & na \\
\hline $10,000-15,000$ & 31.5 & na & 43.9 & na & 47.8 & na \\
\hline $15,000-20,000$ & 32.6 & na & 42.2 & na & 52.9 & na \\
\hline More than 20,000 & 34.9 & na & 44.7 & na & 46.7 & na \\
\hline
\end{tabular}

priority since the implementation of the National Health Mission in India. In last decade, over half of the national health budget is spent on maternal care, and the state governments supplement to the national spending of the respective states. The JSY, under NHM is one the largest ever cash assistance programme worldwide. The NHM had been successful in reduction of maternal and child mortality and increasing maternal care, but studies suggest that the extent of OOPE and CHS continue to be high on maternal care $[23,60]$. People continue to resort to different means such as selling assets, selling property and borrowing with and without interest to meet the expenses on delivery care. Studies examined the extent of distress financing on health care in India and a few

Table 4 Concentration Index for institutional Delivery by Source of Financing in Selected States of India, 2015-16

\begin{tabular}{|c|c|c|c|c|}
\hline State & Only Saving & Only Selling and Borrowing & $\begin{array}{l}\text { Savings along with Selling } \\
\text { and Borrowing }\end{array}$ & Distress Financing \\
\hline Andhra Pradesh & 0.028 & -0.081 & 0.011 & -0.057 \\
\hline Assam & 0.118 & -0.308 & -0.06 & -0.218 \\
\hline Bihar & 0.110 & -0.185 & 0.035 & -0.150 \\
\hline Chhattisgarh & 0.109 & -0.294 & 0.111 & -0.154 \\
\hline Delhi & 0.065 & -0.390 & -0.130 & -0.305 \\
\hline Gujarat & 0.094 & -0.323 & -0.03 & -0.189 \\
\hline Haryana & 0.121 & -0.353 & -0.037 & -0.271 \\
\hline Himachal Pradesh & 0.028 & -0.442 & -0.050 & -0.306 \\
\hline Jammu and Kashmir & 0.077 & -0.389 & -0.172 & -0.312 \\
\hline Jharkhand & 0.057 & -0.209 & 0.119 & -0.053 \\
\hline Karnataka & 0.072 & -0.118 & 0.153 & -0.052 \\
\hline Kerala & 0.073 & -0.353 & -0.257 & -0.316 \\
\hline Madhya Pradesh & 0.131 & -0.196 & 0.088 & -0.152 \\
\hline Maharashtra & 0.073 & -0.206 & -0.049 & -0.171 \\
\hline Manipur & 0.124 & -0.263 & -0.236 & -0.247 \\
\hline Meghalaya & 0.108 & -0.416 & -0.087 & -0.263 \\
\hline Odisha & 0.113 & -0.232 & -0.024 & -0.173 \\
\hline Punjab & 0.095 & -0.366 & -0.042 & -0.201 \\
\hline Rajasthan & 0.037 & -0.227 & 0.006 & -0.145 \\
\hline Tamil Nadu & 0.071 & -0.143 & 0.170 & -0.080 \\
\hline Telangana & 0.115 & -0.194 & 0.067 & -0.148 \\
\hline Tripura & 0.068 & -0.187 & -0.043 & -0.161 \\
\hline Uttar Pradesh & 0.079 & -0.258 & 0.037 & -0.149 \\
\hline Uttarakhand & 0.067 & -0.286 & 0.029 & -0.179 \\
\hline West Bengal & 0.111 & -0.276 & 0.034 & -0.194 \\
\hline India & 0.084 & -0.235 & 0.000 & -0.171 \\
\hline
\end{tabular}




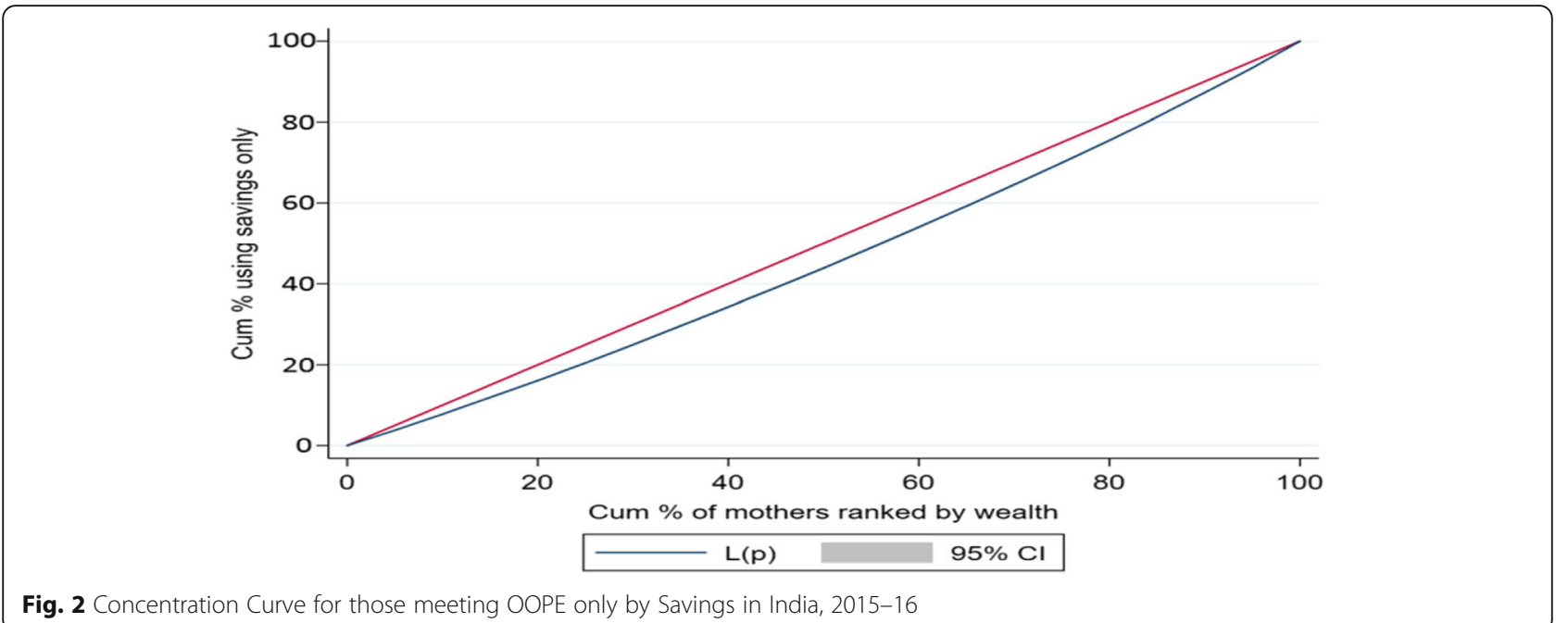

Fig. 2 Concentration Curve for those meeting OOPE only by Savings in India, 2015-16

have quantified it to delivery care [20, 45]. For the first time, the NFHS 4 provides information on out-of-pocket expenditure as well as source of meeting the delivery care expenses along with other maternal, child and household characteristics. In this paper, we have estimated the extent of distress financing and examined the correlates of distress financing in India using NFHS 4 data. We present the salient findings and provide plausible explanation of our findings.

First, the OOPE on institutional delivery has a strong economic and educational gradient and the findings are robust across the states of India. The OOPE on delivery care was high in private health centers, for pregnancy complications and caesarean births.. The state variation in OOPE on institutional delivery was large- higher in economically better off states and lower in the poorer states of India. This finding is consistent with literature $[45,58,61]$. Second, about two-fifths of the mothers utilized their savings, onefifth of them resorted to only selling and borrowing, while one in seven mothers borrowed/sold assets in addition to using their savings to meet the OOPE on institutional delivery. The extent of distress financing was higher among the poorer, less educated mothers, in private health centers and for caesarean delivery. Only one in ten mothers did not pay for OOPE. Third, the OOPE on institutional delivery is positively associated with distress financing. While the OOPE on delivery was almost similar for those who used only saving and those who borrowed money or sold assets to meet the cost of delivery care, it was $70 \%$ higher for those who used savings in addition to borrowing or selling assets. Controlling for socio-economic correlates, the predicted probability of incurring distress financing

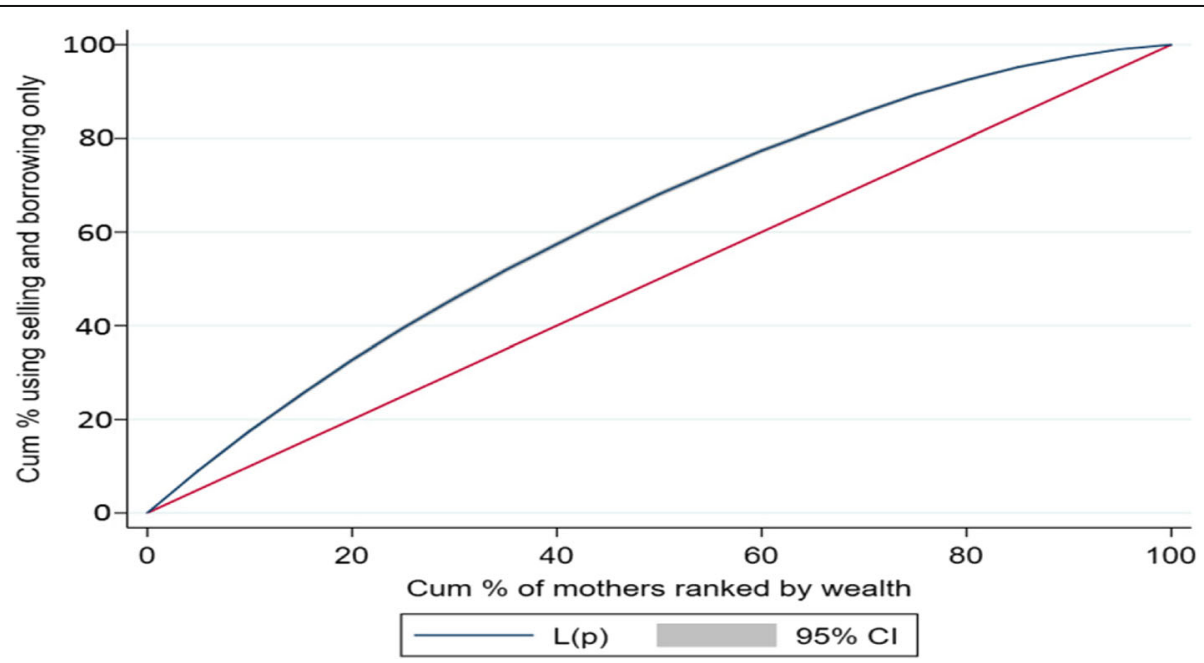

Fig. 3 Concentration Curves for those meeting OOPE by only Selling and Borrowing in India, 2015-16 


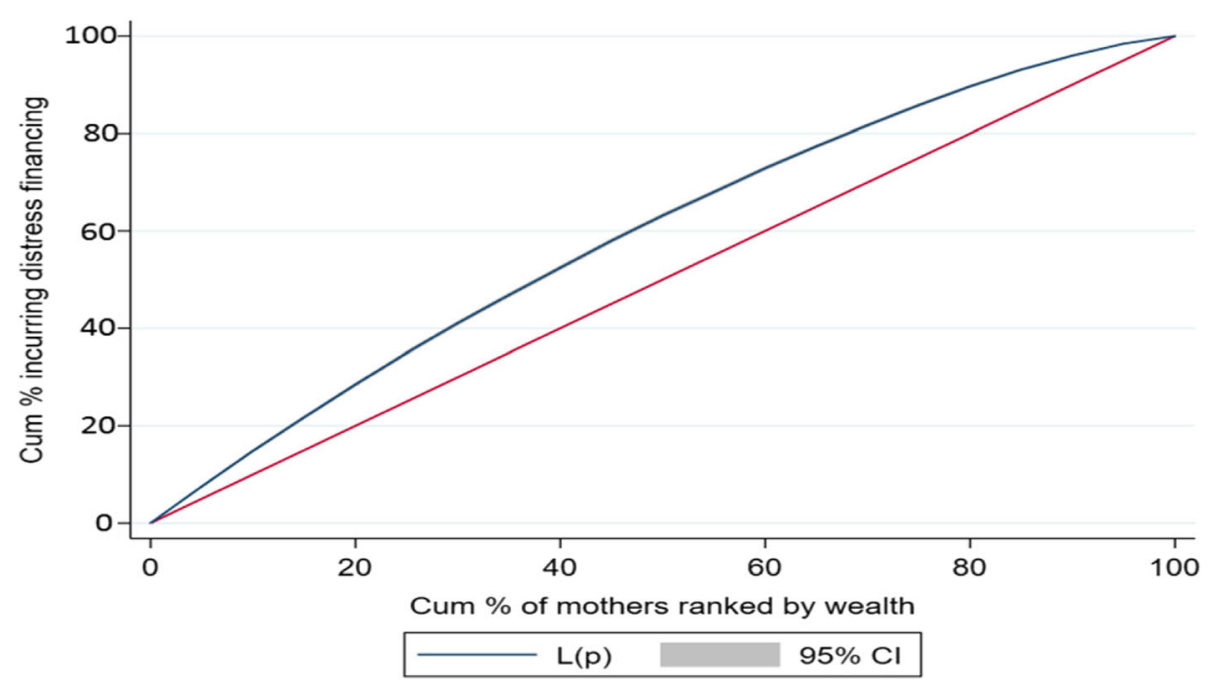

Fig. 4 Concentration Curves for Incurring Distress Financing for Institutional delivery in India, 2015-16

was 0.41 among those spent INR 20,000 and above compared to 0.09 among those who spent less than INR 1000. Fourth, the state pattern of OOPE and distress financing is mixed. While only $13 \%$ of the mothers did not pay for institutional delivery, it was over $25 \%$ in Haryana, Himachal Pradesh and Madhya Pradesh and less than 10\% in Bihar, Uttar Pradesh, West Bengal and Manipur. The extent of distress financing was also high in the states of Bihar, Telangana, Andhra Pradesh West Bengal and Odisha. It is interesting to note that the national average of OOPE among mothers who met OOPE by saving only and selling and borrowing only was almost similar while those met through savings along with borrowing and selling was approximately twice higher. Fifth, the CI value of distress financing for institutional delivery was -0.171 suggesting that the extent of distress financing is largely concentrated among the poor. The $\mathrm{CI}$ value was higher for mothers belonging to poor households who met health spending through borrowing and selling only $(-0.235)$. The state pattern of $\mathrm{CI}$ values for mothers who met OOPE through savings only and through saving along with selling or borrowing are robust across states of India. It further suggests that the inequality in meeting the OOPE through selling and borrowing was largely concentrated among the poor. These estimates are in expected directions.

We provide some plausible explanations in support of our results. Despite one and half decades of implementation of NHM that provides free delivery care in public health centers and entitles cash assistance, about onefourth of the mothers resort to borrowing or selling asset to meet the OOPE on institutional delivery. This is possibly due to high OOPE resulting from increasing use of private health centers, increasing caesarean delivery and pregnancy complications. A recent study suggests that the OOPE of a caesarean delivery in a private health center was at least ten time that of a normal delivery [58]. Such high OOPE on delivery care might be leading to high distress financing. Those who utilized their savings in addition to borrowing and selling of assets paid almost twice the amount paid by those using saving only or selling and borrowing only and are more likely to face distress financing. Besides, the interstate variation in OOPE and distress financing suggests that the provisioning of medicine, tests and other charges in public health centers vary across the states of India. Health is a state subject and the pattern of public spending varies largely across the state. It is found that the average spending in public health centers of low performing states is higher than that in high performing states. For example, in Tamil Nadu, patients seeking care from public health centers pay less on tests and medicine compared to patients in Bihar and Uttar Pradesh [62, 63]. Such variations might be leading to high OOPE and distress financing on delivery care. The extent of distress financing was higher in Telangana, Bihar and other poorer states in India. About half of the delivery in Telangana were caesarean confirming that high caesarean births lead to distress financing. Similarly, in the poorer states of Bihar and Uttar Pradesh, there is inadequate provisioning of medicine and diagnostics in public health centers that might be leading to high distress financing on institutional delivery [64]. The CI value of -0.235 for those using selling and borrowing to meet the OOPE for institutional delivery suggests that the extent of distress financing is higher among mothers from poor households. This suggests that poor people are mostly affected due to high OOPE. Though the JSY and other state specific schemes are operational that provide financial assistance to the poor, the amount stipulated is not sufficient to meet the cost of delivery care. Thus, the high OOPE forces poor mothers to resort for alternative sources of financing in meeting the OOPE on institutional delivery. 
Table 5 Predicted probabilities of Incurring Distress Financing on Institutional Delivery by Selected Socio-Demographic Characteristics in India, Bihar and Telangana, 2015-16

\begin{tabular}{|c|c|c|c|c|c|c|}
\hline \multirow[b]{2}{*}{ Variables } & \multicolumn{2}{|l|}{ India } & \multicolumn{2}{|l|}{ Bihar } & \multicolumn{2}{|l|}{ Telangana } \\
\hline & $\begin{array}{l}\text { Predictive } \\
\text { Probability }\end{array}$ & $\begin{array}{l}95 \% \text { Confidence } \\
\text { Interval }\end{array}$ & $\begin{array}{l}\text { Predictive } \\
\text { Probability }\end{array}$ & $\begin{array}{l}95 \% \text { Confidence } \\
\text { Interval }\end{array}$ & $\begin{array}{l}\text { Predictive } \\
\text { Probability }\end{array}$ & $\begin{array}{l}95 \% \text { Confidence } \\
\text { Interval }\end{array}$ \\
\hline \multicolumn{7}{|l|}{ Place of Residence } \\
\hline Urban & 0.194 & $(0.189,0.199)$ & 0.273 & $(0.245,0.302)$ & 0.355 & $(0.306,0.404)$ \\
\hline Rural & 0.186 & $(0.183,0.189)$ & 0.321 & $(0.311,0.330)$ & 0.357 & $(0.322,0.393)$ \\
\hline \multicolumn{7}{|l|}{ Mother Age } \\
\hline $15-24$ & 0.195 & $(0.191,0.199)$ & 0.309 & $(0.293,0.326)$ & 0.365 & $(0.324,0.407)$ \\
\hline $25-35$ & 0.185 & $(0.182,0.187)$ & 0.316 & $(0.304,0.329)$ & 0.351 & $(0.315,0.387)$ \\
\hline $35+$ & 0.193 & $(0.180,0.207)$ & 0.355 & $(0.299,0.411)$ & 0.249 & $(-0.029,0.527)$ \\
\hline \multicolumn{7}{|l|}{ Education Level } \\
\hline No education & 0.229 & $(0.223,0.234)$ & 0.348 & $(0.334,0.363)$ & 0.418 & $(0.350,0.486)$ \\
\hline Primary & 0.216 & $(0.210,0.222)$ & 0.320 & $(0.295,0.346)$ & 0.501 & $(0.415,0.587)$ \\
\hline Secondary & 0.192 & $(0.189,0.196)$ & 0.303 & $(0.285,0.321)$ & 0.358 & $(0.318,0.399)$ \\
\hline Higher & 0.140 & $(0.136,0.144)$ & 0.230 & $(0.206,0.255)$ & 0.271 & $(0.224,0.318)$ \\
\hline \multicolumn{7}{|l|}{ Religion } \\
\hline Hindu & 0.186 & $(0.183,0.188)$ & 0.309 & $(0.299,0.319)$ & 0.361 & $(0.332,0.390)$ \\
\hline Muslim & 0.211 & $(0.205,0.217)$ & 0.350 & $(0.325,0.376)$ & 0.325 & $(0.241,0.409)$ \\
\hline Others & 0.177 & $(0.168,0.186)$ & 0.651 & $(0.339,0.963)$ & 0.343 & $(0.191,0.496)$ \\
\hline \multicolumn{7}{|l|}{ Social Group } \\
\hline Schedule caste & 0.200 & $(0.195,0.205)$ & 0.298 & $(0.279,0.318)$ & 0.339 & $(0.280,0.398)$ \\
\hline Schedule tribe & 0.190 & $(0.184,0.196)$ & 0.337 & $(0.284,0.389)$ & 0.400 & $(0.309,0.491)$ \\
\hline $\mathrm{OBC}$ & 0.190 & $(0.187,0.194)$ & 0.325 & $(0.313,0.337)$ & 0.355 & $(0.320,0.389)$ \\
\hline Others & 0.175 & $(0.170,0.179)$ & 0.294 & $(0.271,0.317)$ & 0.361 & $(0.287,0.436)$ \\
\hline \multicolumn{7}{|l|}{ Birth Order } \\
\hline 1 & 0.183 & $(0.179,0.187)$ & 0.323 & $(0.303,0.342)$ & 0.339 & $(0.294,0.384)$ \\
\hline 2 & 0.187 & $(0.184,0.191)$ & 0.312 & $(0.295,0.329)$ & 0.364 & $(0.326,0.402)$ \\
\hline 3 & 0.191 & $(0.185,0.196)$ & 0.321 & $(0.302,0.341)$ & 0.374 & $(0.303,0.444)$ \\
\hline $4+$ & 0.203 & $(0.196,0.209)$ & 0.304 & $(0.284,0.324)$ & 0.353 & $(0.215,0.492)$ \\
\hline \multicolumn{7}{|l|}{ Source of Delivery } \\
\hline Public facility & 0.188 & $(0.185,0.191)$ & 0.327 & $(0.315,0.339)$ & 0.327 & $(0.275,0.378)$ \\
\hline Private facility & 0.188 & $(0.183,0.194)$ & 0.282 & $(0.258,0.305)$ & 0.373 & $(0.336,0.411)$ \\
\hline \multicolumn{7}{|l|}{ Type of Delivery } \\
\hline Normal Delivery & 0.183 & $(0.180,0.185)$ & 0.312 & $(0.302,0.322)$ & 0.317 & $(0.274,0.360)$ \\
\hline Caesarean Delivery & 0.211 & $(0.206,0.217)$ & 0.339 & $(0.303,0.374)$ & 0.381 & $(0.346,0.416)$ \\
\hline \multicolumn{7}{|l|}{ Wealth Quintile } \\
\hline Poorest & 0.313 & $(0.305,0.320)$ & 0.394 & $(0.379,0.409)$ & 0.453 & $(0.341,0.565)$ \\
\hline Poorer & 0.255 & $(0.249,0.260)$ & 0.306 & $(0.289,0.323)$ & 0.383 & $(0.318,0.449)$ \\
\hline Middle & 0.201 & $(0.196,0.205)$ & 0.239 & $(0.217,0.261)$ & 0.406 & $(0.355,0.457)$ \\
\hline Richer & 0.150 & $(0.146,0.155)$ & 0.191 & $(0.164,0.219)$ & 0.362 & $(0.314,0.411)$ \\
\hline Richest & 0.084 & $(0.080,0.087)$ & 0.113 & $(0.077,0.149)$ & 0.222 & $(0.161,0.282)$ \\
\hline \multicolumn{7}{|l|}{ JSY Assistance } \\
\hline No & 0.189 & $(0.186,0.192)$ & 0.331 & $(0.314,0.347)$ & 0.359 & $(0.331,0.388)$ \\
\hline Yes & 0.188 & $(0.184,0.191)$ & 0.303 & $(0.290,0.316)$ & 0.337 & $(0.257,0.417)$ \\
\hline
\end{tabular}

Mean OOPE 
Table 5 Predicted probabilities of Incurring Distress Financing on Institutional Delivery by Selected Socio-Demographic Characteristics in India, Bihar and Telangana, 2015-16 (Continued)

\begin{tabular}{|c|c|c|c|c|c|c|}
\hline \multirow[b]{2}{*}{ Variables } & \multicolumn{2}{|l|}{ India } & \multicolumn{2}{|l|}{ Bihar } & \multicolumn{2}{|l|}{ Telangana } \\
\hline & $\begin{array}{l}\text { Predictive } \\
\text { Probability }\end{array}$ & $\begin{array}{l}\text { 95\% Confidence } \\
\text { Interval }\end{array}$ & $\begin{array}{l}\text { Predictive } \\
\text { Probability }\end{array}$ & $\begin{array}{l}95 \% \text { Confidence } \\
\text { Interval }\end{array}$ & $\begin{array}{l}\text { Predictive } \\
\text { Probability }\end{array}$ & $\begin{array}{l}\text { 95\% Confidence } \\
\text { Interval }\end{array}$ \\
\hline $0-1000$ & 0.085 & $(0.083,0.088)$ & 0.221 & $(0.207,0.236)$ & 0.137 & $(0.098,0.175)$ \\
\hline $1000-5000$ & 0.215 & $(0.211,0.219)$ & 0.316 & $(0.303,0.329)$ & 0.272 & $(0.216,0.328)$ \\
\hline $5000-10,000$ & 0.290 & $(0.282,0.297)$ & 0.429 & $(0.395,0.463)$ & 0.408 & $(0.339,0.477)$ \\
\hline $10,000-15,000$ & 0.328 & $(0.317,0.339)$ & 0.476 & $(0.424,0.528)$ & 0.476 & $(0.403,0.549)$ \\
\hline $15,000-20,000$ & 0.368 & $(0.352,0.383)$ & 0.503 & $(0.433,0.573)$ & 0.486 & $(0.389,0.583)$ \\
\hline $20,000+$ & 0.408 & $(0.396,0.419)$ & 0.560 & $(0.512,0.607)$ & 0.551 & $(0.495,0.606)$ \\
\hline
\end{tabular}

Even among mothers who received JSY assistance, onefourth of the mothers incurred distress financing to manage the expenditure on institutional delivery. Thus not only the outreach of JSY remains low, the assistance provided is also insufficient to cover the expenditure incurred on institutional delivery.

In January 2017, the Government of India introduced Pradhan Mantri Matru Vandana Yojana (PMMVY) that stipulated partial compensation or the wage loss in the form of cash assistance of INR 5000 to pregnant and lactating mothers. A sum of INR 1000 is given on early registration of pregnancy at the Anganwadi Centre (AWC) / Approved Health facility, INR 2000 after 6 months of pregnancy on receiving at least one ante-natal check-up (ANC) and a sum of INR 2000 after child birth is registered and the child has received the first cycle of Bacillus Calmette Guerin (BCG), Oral Polio Vaccine (OPV), Diphtheria, Pertussis, Tetanus (DPT) and Hepatitis B, or its equivalent/ substitute. It aims at improving the health seeking behaviour amongst pregnant women and lactating mothers.

Although this study provides estimates of distress financing and its correlates of institutional delivery, it has certain limitations. First, we have not quantified the extent of borrowing and selling of assets due to data limitations. Data on the amount of borrowing and selling would have been helpful to understand the extent of indebtedness. Second, we could not assess the short run and long run indebted ness due to borrowing and selling of assets. Borrowing from money lenders at a high rate of interest affects the welfare of the household in the long run. Third, the OOPE incurred by mothers on delivery care may have recall bias and did not include the recent benefit under PMMVY. Despite these limitations, this paper provides comprehensive and robust estimates of distress financing in India.

\section{Conclusion}

Our study highlights the presence of strong economic and educational gradient in OOPE associated with institutional delivery in India. Further, factors such as lower economic status, use of private health centres, having caesarean births increased the likelihood of OOPE on institutional delivery in India. Mothers resorted to various coping strategies to meet the OOPE on institutional delivery and hence reduction of distress financing requires reduction of OOPE on delivery care. This can be made possible by reducing the number of caesarean births whenever permissible, improving the services in public health centers, improving the availability of medicine and supplies, diagnostic services and effective implementation of maternity benefit schemes at national and state level. We further suggests that the coverage and benefits provided by various centrally sponsored schemes should be strengthened, monitored and regulated periodically. The state government has a greater role to play in the effective implementation of NHM. Also, populationbased surveys should collect information on the amounts borrowed with or without interest and the value of assets sold to understand the degree of distress financing.

\section{Endnotes}

${ }^{1}$ Public source include government/municipal hospital, government dispensary, urban health centers, community health centers, sub-centers, rural hospital and other public health facilities while private source include hospitals, maternity home, clinic, non-governmental organization (NGO), trust hospital, clinic and other private sector facility.

${ }^{2}$ Wealth quintile was derived from the wealth index that was created using Principal Component Analysis (PCA) for a set of 43 consumer durables for rural and urban areas separately. The consumer durables included source of drinking water, type of toilet facility, type of cooking fuel, main material of floor, main roof material and others household assets.

\section{Abbreviations}

ANC: Ante-natal Checkup; AWC: Anganwadi Centre; BCG: Bacillus Calmette Guerin; CC: Concentration Curve; CHI: Community Health Insurance; CHS: Catastrophic Health Spending; Cl: Concentration Index, Confidence Interval; DPT: Diphtheria, Pertussis, Tetanus; ET: Epidemiological Transition; HPS: High Performing States; JSSK: Janani Shishu Suraksha Karyakram; JSY: Janani Suraksha Yojana; LPS: Low Performing States; NFHS: National 
Family Health Survey; NGO: Non-governmental Organisation; NHM: National Health Mission; OBC: Other Backward Caste; OOPE: Out of Pocket Expenditure; OPV: Oral Polio Vaccine; PMMVY: Pradhan Mantri Matru Vandana Yojana; RSBY: Rashtriya Swasthya Bima Yojana; SC: Scheduled Caste; ST: Scheduled Tribe; UT: Union Territory

\section{Authors' contributions}

Conception and design of study: SM and SKM, Analysis and/or interpretation of data: SM and SKM; drafting the manuscript: SM and SKM; revising the manuscript critically for important content: SKM. The manuscript was prepared under overall supervison of SKM. Both authors read and approved the final manuscript

\section{Funding}

We declare that we have not receive any funding for this work.

\section{Availability of data and materials}

The dataset used and analysed for the current study is available in DHS repository, [https://dhsprogram.com/data/dataset/India_Standard-DHS_2015. cfm?flag=0].

\section{Ethics approval and consent to participate}

As the survey is based on secondary data and available in public domain, it needs no prior approval.

\section{Consent for publication}

This manuscript is an original work written by the authors, SM and SKM who are aware of its content and approve its submission. IT is also important to mention that the manuscript has not been published elsewhere in part or in entirety, and is not under consideration by another journal. All authors gave their consent for publication in the International Journal for Equity in Health.

\section{Competing interests}

The authors declare that they have no competing interest.

\section{Author details}

${ }^{1}$ International Institute for Population Sciences, Govandi Station Road, Deonar, Mumbai 400088, India. ${ }^{2}$ Department of Fertility Studies, International Institute for Population Sciences, Govandi Station Road, Deonar, Mumbai 400088, India.

\section{Received: 9 January 2019 Accepted: 10 June 2019}

Published online: 25 June 2019

\section{References}

1. Garg CC, Karan AK. Reducing out-of-pocket expenditures to reduce poverty: a disaggregated analysis at rural-urban and state level in India. Health Policy Plan. 2009;24(2):116-28.

2. Roy K, Howard DH. Equity in out-of-pocket payments for hospital care: evidence from India. Health Policy (New York). 2007:80(2):297-307.

3. Van Damme W, Van Leemput L, Por I, Hardeman W, Meessen B. Out-ofpocket health expenditure and debt in poor households: evidence from Cambodia. Trop Med Int Heal. 2004;9(2):273-80.

4. Falkingham J. Poverty, out-of-pocket payments and access to health care: evidence from Tajikistan. Soc Sci Med. 2004:58(2):247-58.

5. Wagstaff A, Flores G, Hsu J, Smitz MF, Chepynoga K, Buisman LR, et al. Progress on catastrophic health spending in 133 countries: a retrospective observational study. Lancet Glob Heal. 2018;6(2):e169-79.

6. Pandey A, Ploubidis GB, Clarke L, Dandona L. Trends in catastrophic health expenditure in India: 1993 to 2014. Bull World Health Organ [Internet]. 2018; 96(1):18-28 Available from: http://www.who.int/entity/bulletin/volumes/96/ 1/17-191759.pdf.

7. Brinda EM, Andrés RA, Enemark U. Correlates of out-of-pocket and catastrophic health expenditures in Tanzania: results from a national household survey. BMC Int Health Hum Rights [Internet]. 2014;14(1):5 Available from: https://bmcinthealthhumrights.biomedcentral.com/articles/ 10.1186/1472-698X-14-5.

8. UN. Final list of proposed Sustainable Development Goal indicators. Rep Inter-Agency Expert Gr Sustain Dev Goal Indic [Internet]. 2015;Annex IV. Available from: https://sustainabledevelopment.un.org/content/documents/ 11803Official-List-of-Proposed-SDG-Indicators.pdf
9. Wagstaff A, Flores G, Smitz MF, Hsu J, Chepynoga K, Eozenou P. Progress on impoverishing health spending in 122 countries: a retrospective observational study. Lancet Glob Health. 2018;6(2):e180-92.

10. Krishna A. Escaping poverty and becoming poor: who gains, who loses, and why? World Dev [Internet]. 2004;32(1):121-36 Available from: https:// linkinghub.elsevier.com/retrieve/pii/\$0305750X0300192X.

11. Krishna A. Pathways out of and into poverty in 36 villages of Andhra Pradesh, India. World Dev [Internet]. 2006;34(2):271-288. Available from: https://linkinghub.elsevier.com/retrieve/pii/S0305750X05002044.

12. Dercon S. Income risk, coping strategies, and safety nets. World Bank Res Obs [Internet]. 2002;17(2):141-66 Available from: https://academic.oup.com/ wbro/article-lookup/doi/10.1093/wbro/17.2.141.

13. Flores G, Krishnakumar J, O'Donnell O, Van Doorslaer E. Coping with healthcare costs: implications for the measurement of catastrophic expenditures and poverty. Health Econ. 2008;17(12):1393-412.

14. Kastor A, Mohanty SK. Disease-specific out-of-pocket and catastrophic health expenditure on hospitalization in India: do Indian households face distress health financing? PLoS One. 2018;13(5):1-18.

15. Joe W. Distressed financing of household out-of-pocket health care payments in India: incidence and correlates. Health Policy Plan. 2015;30(6):728-41.

16. Karan A, Engelgau M, Mahal A. The household-level economic burden of heart disease in India. Trop Med Int Heal. 2014;19(5):581-91.

17. Binnendijk E, Koren R, Dror DM. Hardship financing of healthcare among rural poor in Orissa, India. BMC Health Serv Res. 2012;12(1).

18. Ezeoke OP, Onwujekwe OE, Uzochukwu BS. Towards universal coverage: examining costs of illness, payment, and coping strategies to different population groups in Southeast Nigeria. Am J Trop Med Hyg. 2012;86(1):52-7.

19. Tambor M, Pavlova M, Rechel B, Golinowska S, Sowada C, Groot W. The inability to pay for health services in central and Eastern Europe: evidence from six countries. Eur J Pub Health. 2014;24(3):378-85.

20. John D, Kumar V. Exposure to hardship financing for healthcare among rural poor in Chhattisgarh, India. J Health Manag. 2017;19(3):387-400.

21. Pannarunothai S, Mills A. The poor pay more: health-related inequality in Thailand. Soc Sci Med. 1997;44(12):1781-90.

22. WHO. The World Health Report: Health systems financing: The path to Universal Coverage. Geneva: World Health Organization; 2010.

23. Bonu S, Bhushan I, Rani M, Anderson I. Incidence and correlates of "catastrophic" maternal health care expenditure in India. Health Policy Plan. 2009;24(6):445-56.

24. Steven R. Review article ability to pay for health care: concepts and evidence. Program Financ Unit Heal Policy. 1996;11(3):219-37.

25. Sauerborn R, Adams A, Hien M. Household strategies to cope with the economic costs of illness. Soc Sci Med. 1996;43(3):291-301.

26. Tahsina T, Ali NB, Siddique AB, Ahmed S, Rahman M, Islam S, et al. Determinants of hardship financing in coping with out of pocket payment for care seeking of under five children in selected rural areas of Bangladesh. PLoS One. 2018;13(5):1-17.

27. Hoque ME, Dasgupta SK, Naznin E, Al Mamun A. Household coping strategies for delivery and related healthcare cost: findings from rural Bangladesh. Trop Med Int Heal. 2015;20(10):1368-75.

28. Kruk ME, Goldmann E, Galea S. Borrowing and selling to pay for health care in low- and middle-income countries. Health Aff. 2009;28(4):1056-66.

29. Bonu S, Rani M, Peters DH, Jha P, Nguyen SN. Does use of tobacco or alcohol contribute to impoverishment from hospitalization costs in India? Health Policy Plan. 2005;20(1):41-9.

30. Essue B, Kelly P, Roberts M, Leeder S, Jan S. We can't afford my chronic illness! The out-ofpocket burden associated with managing chronic obstructive pulmonary disease in western Sydney, Australia. J Heal Serv Res Policy. 2011;16(4):226-31.

31. Cleary S, Birch S, Chimbindi N, Silal S, Mclntyre D. Investigating the affordability of key health services in South Africa. Soc Sci Med. 2013;80:37-46.

32. Mock CN, Gloyd S, Adjei S, Acheampong F, Gish O. Economic consequences of injury and resulting family coping strategies in Ghana. Accid Anal Prev. 2003;35(1):81-90.

33. Daivadanam M, Thankappan KR, Sarma PS, Harikrishnan S. Catastrophic health expenditure \& coping strategies associated with acute coronary syndrome in Kerala, India. Indian J Med Res [Internet]. 2012;136(4):585-92 Available from: https://www.ncbi.nlm.nih.gov/pmc/articles/PMC3516025/.

34. Husøy OK, Molla SM, Muluken G, Marie MK, Frithof NO, Ingrid M. Selling my sheep to pay for medicines - household priorities and coping strategies in a setting without universal health coverage. BMC Health Serv Res. 2018;18(1):1-12.

35. Kabir MA, Rahman A, Salway S, Pryer J. Sickness among the urban poor: a barrier to livelihood security. J Int Dev. 2000;12(5):707-22. 
36. Mclntyre D, Thiede M, Dahlgren G, Whitehead M. What are the economic consequences for households of illness and of paying for health care in low- and middle-income country contexts? Soc Sci Med. 2006;62(4):858-65.

37. Chuma J, Gilson L, Molyneux C. Treatment-seeking behaviour, cost burdens and coping strategies among rural and urban households in coastal Kenya: an equity analysis. Trop Med Int Heal. 2007;12(5):673-86.

38. Okediji PT, Ojo AO, Ojo Al, Ojo AS, Ojo OE, Abioye-Kuteyi EA. The economic impacts of chronic illness on households of patients in Ile-lfe, SouthWestern Nigeria. Cureus. 2017;9(10).

39. Datta BK, Husain MJ, Husain MM, Kostova D. Noncommunicable diseaseattributable medical expenditures, household financial stress and impoverishment in Bangladesh. SSM - Popul Heal [Internet]. 2018;6(June): 252-8. Available from: https://doi.org/10.1016/j.ssmph.2018.10.001

40. Alamgir NI, Naheed A, Luby SP. Coping strategies for financial burdens in families with childhood pneumonia in Bangladesh. BMC Public Health [Internet]. 2010;10(1):622 Available from: https://bmcpublichealth. biomedcentral.com/articles/10.1186/1471-2458-10-622.

41. Leive A, Xu K. Coping with out-of-pocket health payments: empirical evidence from 15 African countries. Bull World Health Organ. 2008:86(11):849-56.

42. Dilip TR, Duggal R. Incidence of non-fatal health outcomes and debt in urban India. Mumbai: CEHAT; 2002

43. Perkins M, Brazier E, Themmen E, Bassane B, Diallo D, Mutunga A, et al. Outof-pocket costs for facility-based maternity care in three African countries. Health Policy Plan [Internet]. 2009;24(4):289-300 Available from: https:// academic.oup.com/heapol/article-lookup/doi/10.1093/heapol/czp013.

44. Skordis-Worrall J, Pace N, Bapat U, Das S, More NS, Joshi W, Pulkki-Brannstrom AM, Osrin D. Maternal and neonatal health expenditure in Mumbai slums (India): a cross sectional study. BMC Public Health. 2011;11(1):150.

45. Modugu HR, Kumar M, Kumar A, Millett C. State and socio-demographic group variation in out-of-pocket expenditure, borrowings and Janani Suraksha Yojana (JSY) programme use for birth deliveries in India. BMC Public Health. 2012;12(1):1048.

46. Ministry of Health and Family Welfare, Government of India. National Health Accounts, India 2004-05. 2009. Available from: http://planningcommission. nic.in/reports/genrep/health/National_Health_Account_04_05.pdf.

47. Ministry of Health and Family Welfare, Government of India. National Health Accounts, India 2013-14. 2016. Available from: https://mohfw.gov.in/sites/ default/files/89498311221471416058.pdf.

48. Ministry of Health and Family Welfare, Government of India. National Health Accounts, India 2014-15. 2017. Avaiable from: https://mohfw.gov.in/sites/default/ files/National\%20Health\%20Accounts\%20Estimates\%20Report\%202014-15.pdf.

49. Lim SS, Dandona L, Hoisington JA, James SL, Hogan MC, Gakidou E. India's Janani Suraksha Yojana, a conditional cash transfer programme to increase births in health facilities: an impact evaluation. Lancet [Internet]. 2010; 375(9730):2009-23 Available from: http://citeseerx.ist.psu.edu/viewdoc/ download?doi=10.1.1.459.9783\&rep=rep1\&type=pdf.

50. Karan A, Yip W, Mahal A. Extending health insurance to the poor in India: an impact evaluation of Rashtriya Swasthya Bima Yojana on out of pocket spending for healthcare. Soc Sci Med. 2017;181:83-92.

51. Tripathi N, Saini SK, Prinja S. Impact of Janani Shishu Suraksha Karyakram on out-of-pocket expenditure among urban slum dwellers in northern India. Indian Pediatr. 2014;51(6):475-7.

52. Dandona L, Dandona R, Kumar GA, Shukla DK, Paul VK, Balakrishnan K, Prabhakaran D, Tandon N, Salvi S, Dash AP, Nandakumar A. Nations within a nation: variations in epidemiological transition across the states of India, 19902016 in the global burden of disease study. Lancet. 2017;390(10111):2437-60.

53. Suryanarayana MH, Agrawal A, Prabhu KS. Inequality- adjusted Human Development Index for India's States 2011 United Nations Development Programme 55, Lodi Estate New Delhi -110003 India. UNDP India [Internet]. 2011;1-31. Available from: https:/www.undp.org/content/dam/india/docs/ inequality_adjusted_human_development_index_for_indias_state1.pdf.

54. Mohanty SK, Kim R, Khan PK, Subramanian SV. Geographic variation in household and catastrophic health spending in India: assessing the relative importance of villages, districts, and states, 2011-2012. Milbank Q. 2018;96(1):167-206.

55. Pankaj SN, Kanchan M. Economic effect of coronary heart disease on households - a study in Mumbai. Int J Med Public Heal. 2016;6(4):184-8.

56. Basumatary J, Nirankar P. Household 's coping mechanisms of out-ofpocket expenditure on health Care : a case study of Assam. India. 2018; 23(1):70-84
57. International Institute for Population Sciences (IIPS) \& ICF: National Family Health Survey (NFHS-4), 2015-16: Mumbai: IIPS; 2017. http://rchiips.org/ NFHS/NFHS-4Reports/India.pdf

58. Mohanty SK, Panda BK, Khan PK, Behera P. Out-of-pocket expenditure and correlates of caesarean births in public and private health centres in India. Soc Sci Med. 2019;224:45-57.

59. Wagstaff A, Paci P, Van Doorslaer E. On the measurement of inequalities in health. Soc Sci Med. 1991;33(5):545-57.

60. Mohanty SK, Kastor A. Out-of-pocket expenditure and catastrophic health spending on maternal care in public and private health centres in India: a comparative study of pre and post national health mission period. Heal Econ Rev. 2017;7(1):31

61. Mohanty SK, Srivastava A. Out-of-pocket expenditure on institutional delivery in India. Health Policy Plan. 2012;28(3):247-62 Available from: https://academic.oup.com/heapol/article-lookup/doi/10.1093/heapol/czs057.

62. Hooda SK. Out-of-pocket payments for healthcare in India: who have affected the Most and why? J Health Manag. 2017;19(1):1-5.

63. Ghosh S. Catastrophic payments and impoverishment due to out-of-pocket health spending. Economic and Political Weekly. 2011:63-70. Available from: https://www.jstor.org/stable/pdf/41720524.pdf?casa_token= JojurhfJKOEAAAAA:OnMMirxFOQNrm6MYgMBSHj0s7FcDNh82xK8CBYPK DmuyoDdPVFkVzg0xbyRbvvMJjLx_Elk3UbAbiHzWN8GHdFofD1dhwe1gTJs90DT_jMcnlTeuA

64. Bhattacharyya S, Issac A, Rajbangshi P, Srivastava A, Avan BI. "Neither we are satisfied nor they"-users and provider's perspective: a qualitative study of maternity care in secondary level public health facilities, Uttar Pradesh, India. BMC Health Serv Res. 2015;15(1):421.

\section{Publisher's Note}

Springer Nature remains neutral with regard to jurisdictional claims in published maps and institutional affiliations.

\section{Ready to submit your research? Choose BMC and benefit from:}

- fast, convenient online submission

- thorough peer review by experienced researchers in your field

- rapid publication on acceptance

- support for research data, including large and complex data types

- gold Open Access which fosters wider collaboration and increased citations

- maximum visibility for your research: over $100 \mathrm{M}$ website views per year

At BMC, research is always in progress.

Learn more biomedcentral.com/submissions 